\title{
An Exploration of the Various Dimensions of Organisational Citizenship Behaviour
}

\author{
Minothi J., J. Arul Suresh
}

\begin{abstract}
This study is an attempt to explore the various aspects of organisational citizenship behaviour among employees. In a world where employee's morale and loyalty are under the scanner, citizenship behaviour offers bright hope for the organisation.A country's citizenship does not merely come by just living in that country; it is gained by meeting the legal requirements of a nation. A country is benefitted by citizens who voluntarily contribute in their ways towards the growth of the nation. Same way when the employees give their best, as they feel responsible along with a strong sense of belongingness for the organisation, they reflect organisational citizenship behaviour. Organisational Citizenship Behaviour (OCB) is the voluntary actions and behaviour by the employees, which are not a part of the job description but benefits in the efficiency of the organisations. The paper' first objective would be to study what induces citizenship behaviour among employees. Personal characteristics and attitudes could play a big part in determining the employee's behaviour. On the other hand, the organisation's policies and environment also is a crucial factor in determining $O C B$. The next objective of the study is to analyse the impact of OCB. Though the positive effect is always favoured, this research explores if there could be any negative impact of citizenship behaviour on the employees. The study is based on the views of 100 respondents who belong to private corporate firms within Chennai city only. The influencers and impact of $O C B$ are discussed as the various dimensions in the study.
\end{abstract}

Keywords: Organisational Citizenship Behaviour (OCB), Influencers, Impact, Employee.

\section{INTRODUCTION}

$T_{\text {he achievements of an organisation are the results of }}$ the combined effort of every employee. Each employee differs, there are underperformers, some employees who exactly do the work assigned to them, and there are few employees who do more than what is required. The latter type of employees who, walk an extra mile or go beyond what is needed for the organisation's growth, are the main subjects for this study. OCB has been studied from the 1970s; initially, the term was discovered by Dennis Organ, who is now regarded as the father of organisational citizenship behaviour. Dennis Organ defines it as "an individual behaviour which is not rewarded by a formal reward system, but that, when combined with the same behaviour in a group,

Revised Manuscript Received on December 05, 2019.

* Correspondence Author

Minothi J. *, Research Scholar, Department of Commerce, Loyola College (Autonomous), Chennai, India. Email:minothititus@gmail.com

Dr. J. Arul Suresh, Assistant Professor, Department of Commerce, Loyola College (Autonomous), Chennai, India. results ineffectiveness." Some examples could be helping a co-worker to finish a project on time, learning new concepts to apply for the betterment of the organisation, speaking highly of the organisation to outsiders, etc. These examples make it easy to understand that these actions are not required to be done, but they benefit the team and excellent organisational functioning.

The five most common type of OCB as given by Dennis Organ will enable the complete understanding of the concept. They are:

Altruism - The desire to assist others without expecting anything in return for that assistance.

Courtesy - Being considerate and polite towards the co-workers.

Sportsmanship - Avoiding negative behaviour even when things do not go as planned.

Conscientiousness - Exercising strict discipline in all areas of work.

Civic Virtue - Representing and supporting the organisation well to the outsiders.

\section{INFLUENCERS OF ORGANISATIONAL CITIZENSHIP BEHAVIOUR (OCB)}

Researchers could debate if citizenship behaviour is a personality trait or whether it is an outcome of an excellent work environment. Both factors equally have a part in deciding this positive behaviour. A cheerful personality would be shunned with a negative work environment and reduced job satisfaction. Hence both the factors are discussed in the study.

Personal factors taken into consideration for the study are boldness, emotional stability, willingness to learn and adapt to changes, concern for colleagues, gratitude and tolerance. These positive characteristics have a strong attachment to citizenship behaviour. The personality traits are usually a part of the employees and cannot be developed and modified to an extent.

The organisational factors included in the study are compensation, recognition, procedural justice, supervisory support, work environment and proper job allotment. Compensation, recognition and good leaders are basic requirements of every employee. Procedural justice is the fair treatment in procedures like promotion, appraisal, and grievance settlements. Employees gain confidence with the management with a fair and transparent procedural justice system. A pleasant work environment with ethical policies and right work 
conditions would motivate the employees to have healthy citizenship behaviour.

An employee mismatched with a job profile will not be interested in the organisation's growth. Hence these above factors should be maintained well by the organisation to induce positive organisation citizenship behaviour.

\section{IMPACT OF ORGANISATION CITIZENSHIP BEHAVIOUR (OCB)}

Organisational citizenship behaviour is seen as a positive impact and as a benefit in most studies. Very few studies have included the downside of this behaviour. This study tries to seek if there could be any negative impact of OCB.

The positive benefits of encouraging employees to engage in OCB would be, an increase in productivity and efficiency. Employees exhibiting OCB would need less supervision and are naturally motivated. The morale of the employees is a reliable indicator of OCB. Employees who have a strong sense of citizenship benefit the goodwill, retention rate and work climate of the organisation.

There are a few adverse outcomes of OCB when it goes beyond what is needed. There could be conflicts and irritation among employees when few of them constantly work following all the rules of the organisation. Employees having work as a priority all the time would gain the confidence of the management and hence would create rivalry among the other employees. When employees give their all towards the organisation growth, there could be a work-life conflict, and they could be stressed with doing things perfectly all the time.

\section{STATEMENT OF THE PROBLEM}

Every organisation would dream of an employee who does not see his/her job as a mere paycheck and strives hard to achieve all the organisational goals without much reinforcement. And when such citizenship employees are found they would be a great treasure the organisation would like to retain. This study focuses on the employees who reflect organisational citizenship behaviour and studies the various elements which motivate them, influence them and also the positive and negative side of such behaviours.

\section{REVIEW OF LITERATURE}

Ella Mittal \& Navneet Kaur (2018), examined the impact of OCB on the employees. There was found to be a positive relationship between OCB and employee retention practices. Altruism and courtesy dimensions showed the maximum effect on OCB while compared to the other factors.

Ptiraj Kumari \& Shivani Thapliyal (2017), highlighted that OCB as a key to organisational efficiency. There was a significant relationship found between OCB and organisational efficiency. Citizenship behaviour can be expected only when the employees are treated and handled well by the organisation.

Mariela Pavalache -Ilie (2013), studied OCB with regard to work satisfaction and employee personality. The results indicated that employees satisfied with their job displayed

higher levels of citizenship behaviour.

Hossan Abu Elanain (2007) analysed the relationship between personality and OCB. Personality traits like openness to new experience, conscientiousness and emotional stability were found to be valid indicators of OCB. Traits like extraversion and agreeableness did not have a direct relationship with OCB in the study.

\section{RESEARCH OBJECTIVES}

1. To find the personal and organisational factors which influence Organisational Citizenship Behaviour (OCB).

2. To discuss the impact of citizenship behaviour on employees and the organisation.

\section{RESEARCH METHODOLOGY}

Primary data has been collected from 100 respondents through questionnaires from various corporate sectors primarily from IT, banking and financial sectors within Chennai city. Convenient sampling method has been utilised for the study. Secondary data has been compiled from books, journals and e-sources. Percentage analysis, ANOVA and T-test method are the statistical tools used for analysing the data.

\section{DATA ANALYSIS AND INTERPRETATION}

Table - 1: Socio-Demographic Profile of the Employees

\begin{tabular}{|c|c|}
\hline $\begin{array}{c}\text { Socio-Demographic Factors \& } \\
\text { Classification }\end{array}$ & Frequency \\
\hline \multicolumn{2}{|l|}{ Gender } \\
\hline Male & 47 \\
\hline Female & 53 \\
\hline \multicolumn{2}{|l|}{ Age } \\
\hline Below 25 & 19 \\
\hline 26-35 Years & 33 \\
\hline $36-45$ Years & 37 \\
\hline Above 45 Years & 11 \\
\hline \multicolumn{2}{|l|}{ Marital Status } \\
\hline Single & 38 \\
\hline Married & 62 \\
\hline \multicolumn{2}{|l|}{ Qualification } \\
\hline Diploma & 2 \\
\hline U.G & 34 \\
\hline P.G & 64 \\
\hline \multicolumn{2}{|l|}{ Work experience } \\
\hline $1-3$ years & 27 \\
\hline $3-10$ years & 31 \\
\hline $10-15$ years & 29 \\
\hline Above 15 years & 13 \\
\hline \multicolumn{2}{|l|}{ Income level } \\
\hline Below 20,000 & 19 \\
\hline $20,000-40,000$ & 41 \\
\hline $40,000-60,000$ & 28 \\
\hline Above 60,000 & 12 \\
\hline
\end{tabular}


From the table, it is found that the gender of the respondents is almost equally distributed, with $47 \%$ of them being male and $53 \%$ being female respondents.

Most of the employees (37\%) are between the age group of $36-45$ years old and $33 \%$ in the $25-35$ years group category. Majority of the women employees are married (62\%), with a post-graduate degree (64\%). Regarding their work experience, $31 \%$ of them had an experience of 3-10 years, and $29 . \%$ of them had between 10 -15 years of work experience. It is seen that most employees $(41 \%)$ have an income level of ₹20,000-₹.40, 000.

\title{
OCB BEHAVIOUR
}

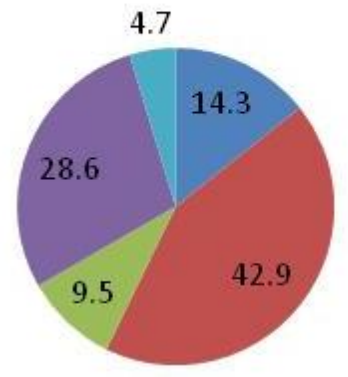

\author{
- Strongly Agree \\ Agree \\ Neutral \\ - Disagree \\ - Strongly Disagree
}

Figure - 1: The number of employees who agreed to have organisational citizenship behaviour.

Organisational citizenship behaviour is a voluntary characteristic. The above chart proves that statement as

Table - 2: t-test for Organisational Citizenship Behaviour Personality Traits

\begin{tabular}{|c|c|c|c|c|c|c|}
\hline & $\mathbf{N}$ & Mean & Std. Deviation & Std. Error Mean & T value & Sig \\
\hline Extroverted and Boldness & 100 & 3.49 & 1.009 & .104 & 24.093 & .000 \\
\hline Concern for co- workers & 100 & 3.00 & 1.082 & .111 & 18.020 & .000 \\
\hline Willingness to learn & 100 & 3.92 & .930 & .095 & 30.554 & .000 \\
\hline Gratitude and Satisfaction & 100 & 3.32 & 1.257 & .129 & 17.957 & .000 \\
\hline Emotional Stability & 100 & 3.61 & 1.075 & .110 & 23.673 & .000 \\
\hline
\end{tabular}

The table output reveals that the $t$ values are statistically significant at $5 \%$ level.

Ho -There is a no significant difference between the work experience of the employee and the impact of OCB

Table- 3: One - way Analysis Variance between the work experience of the employees towards and the impact of OCB

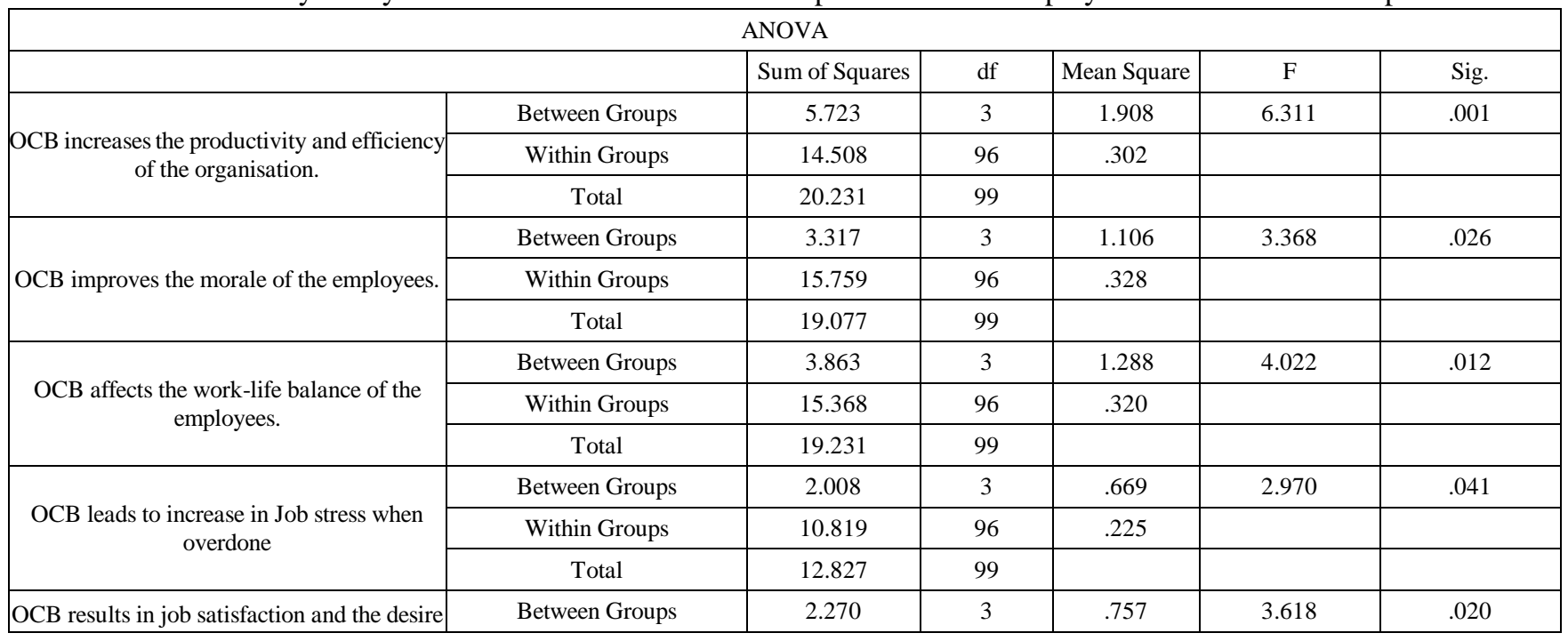




\begin{tabular}{|c|c|c|c|c|c|c|}
\hline to continue with the same organisation. & Within Groups & 10.038 & 96 & .209 & & \\
\cline { 2 - 7 } & Total & 12.308 & 99 & & & \\
\hline
\end{tabular}

The above table it is found that the values are statistically significant @5\% level $(\mathrm{p}<0.05)$, hence the null hypothesis is rejected, and the alternative hypothesis is accepted. Thus there is a significant difference between work experience level of the employees and the impact of OCB.

\section{RESEARCH FINDINGS}

- Both extrovert natured employees (56\%) and introvert natured employees (44\%) exhibit citizenship behaviour in the study. Hence the outgoing nature of the employees is not an indicator of OCB.

- Willingness to participate and learn new changes is strongly associated with OCB as $72 \%$ of the respondents strongly agreed that willingness to participate is a needed personality trait for OCB.

- Emotional stability in terms of tolerance and patience is also a high influencer of citizenship behaviour as $64 \%$ of the respondent's strongly recommended emotional balance as a reliable indicator for OCB.

- Among the organisational factors, procedural justice (42\%) and a pleasant work environment (34\%) comes as the active influencers of OCB.

- Most employees felt that OCB boosts the productivity and efficiency of the organisation.

- Majority of the employees agreed that when work takes all the time, and when they are too attached to work due to their citizenship behaviour, it affects their work-life balance which leads to stress.

- The significant difference between the work experience level of the employees and the impact of OCB explains that with passing years of experience the attachment towards their work would vary.

- There was no significant difference between the gender of the employees and the level of OCB displayed. Hence both male and female employees display citizenship characteristics which depend on the influencers.

- Majority of the employees (77\%) agreed to the statement when OCB is reinforced and expected from the management they have indications to quit the job.

\section{RECOMMENDATIONS}

* The inherent personality of the employees of whether they are introverts, extroverts, or if they stand in between both is not a strong indicator for OCB. The level of their commitment, satisfaction and the drive to do more indicates citizenship behaviour. Hence no personality type should be given an advantage at the workplace.

* In today's world of robust cut-throat competition, citizenship behaviour is encouraged by the organisation. Hence employees should be willing to change and learn new concepts and have a cooperative attitude towards the co-employees at work.

* As the saying "anything in excess is likely bad" when employees take their citizenship behaviour too seriously and are obsessed with perfection, it leads to conflicts among workers, work-life imbalance and stress. Hence the organisation should take measures to motivate the needed behaviour.

* When it comes to healthy citizenship behaviour, employees look more than just compensation and recognition in an organisation. They seek procedural justice in all the dealings of the organisation, the brand image of the organisation and a healthy work environment with ethics. These factors influence OCB more that the monitory factors.

* Finally, organisations have to realise that OCB is a voluntary action, and it cannot be forced or expected from all the employees. When citizenship behaviours are forced, they would not be genuine and would only make the employees look for job options elsewhere.

\section{CONCLUSION}

Organisational citizenship behaviour is a relatively new concept which has surfaced over the last three decades. From then on, the topic is widely researched; there are various dimensions to it that it offers scope for further research and analysis. Since it is a voluntary behaviour of the employees, the indicators and predictors of the behaviour could vary from each employee to employee. When most organisations today struggle with employee turnover, reduced the productivity of employees, burnout, etc. positive reactions like OCB offers hope for the management. When organisations are on the lookout for employees who do their work assigned to them and stay away from negative behaviors; employees who go above and beyond their work are surely an unexpected bonus to the organisation!

\section{REFERENCES}

1. Chaitanya S.K and Nachiketa Tripathi (2001), Dimensions of Organisational Citizenship Behaviour, Indian Journal of Industrial Relations, Vol 37(2), pp 217-230

2. Ella Mittal, Navneet Kaur (2018), Impact of Organisational Citizenship Behaviour on Employee Retention in Banking Sector, International Journal for Research in Engineering Applications and Management, Vol 3 (10), pp 103-112

3. Hossam Abu Elanain (2007), Relationship between Personality and Organisational Citizenship Behaviour: Does Personality Influence Employee Citizenship? , International Review of Business Research Papers, Vol 3(4), pp 31-43

4. Mariela Pavalache-Ilie (2014), Organisational citizenship Behaviour, Work Satisfaction and Employee's Personality, Procedia - Social and Behavioural Sciences, 127, pp 489-493

5. Nadeem Ahmed, Anwar Rasheed,Khawaja Jehanzeb (2012), An Exploration of Predictors of Organisational Citizenship Behaviour and its significant link to Employee Engagement, International Journal of Business Humanities and Technology, Vol 2(4), pp 99-106

6. Patiraj Kumari \& Shivani Thapliyal (2017), Studying the impact of Organisational Citizenship

Behaviour on Organisational Effectiveness. 


\section{AUTHORS PROFILE}

Mrs. Minothi, is a full time research scholar from the Department of Commerce, Loyola College Chennai. The researcher's areas of interests are Human Resource Management, Employee Retention and Women Empowerment. The researcher has three years of work experience. Eight articles have been published and over ten national and international conferences have been attended over the last two years.

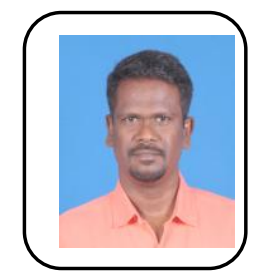

Dr.J.Arul Suresh is an Assistant professor and Research supervisor from the Department of Commerce. Loyola College, Chennai. He has a total work experience of nineteen years. He has a rich research experience and has published more than hundred research articles. He has attended more than hundred and fifty national and international conferences among which he has also been a chief guest and key resource person for certain conferences. He has held prestigious posts like President for commerce forum and Research Co-ordinator over the past years. 